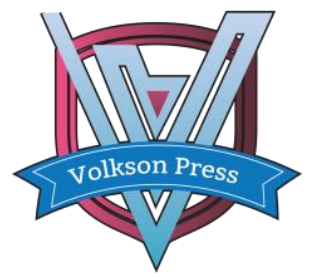

Contents List available at VOLKSON PRESS

Economics \& Management Innovations(EMI)

DOI : http://doi.org/10.26480/icemi.01.2017.165.167

\title{
How Do Managers Get Ambidexterity?
}

\author{
Xinghua Zhao, Hongjiang Lyu', Liang Wu \\ School of Economics and Management of Southeast University, Nanjing, China \\ *luj602@163.com
}

This is an open access article distributed under the Creative Commons Attribution License, which permits unrestricted use, distribution, and reproduction in any medium, provided the original work is properly cited.

\section{ARTICLE DETAILS}

\section{Article History:}

Received 02 october 2017

Accepted 06 october 2017

Available online 11 october 2017

\section{Keywords:}

Formal

network, Informal

emotional network, Consistency between formal and informal emotional network, Contextual ambidexterity, Complex adaptive system.

\section{ABSTRACT}

To better study managers' contextual ambidextrous abilities, this research investigates the relationship between managers' network consistency and contextual ambidexterity based on complex adaptive system theory in dynamic and complex environment. The theory is tested by using primary survey data from organizational members. The author collected 108 data at the managers' level. Through hierarchical regression analyses, the conclusion is that the consistency between managers' formal network and informal emotional network first low and then increase contextual ambidexterity abilities in a U-shaped relationship. Theoretical contributions and empirical results of this paper improve our understanding about managers' contextual ambidexterity in social network perspective.

\section{Introduction}

In dynamic and complex environment, managers have no choice but to balance the paradox and conflict simultaneously existing in organizational context- such as flexibility and efficiency, low-cost and differentiation, alignment and adaptability [1]. with the development of paradoxical thinking, increasingly research recognized the importance of the processes and systems present in given context to balance opposing demands. The term of contextual ambidexterity was used to explain this phenomenon. Contextual ambidexterity was a multidimensional construct with exploration and exploitation constituted by a separate but interrelated, non-substitutable element [2]. But current studies consider context ambidexterity at the business unit or firm level, few focus on the individual level. Therefore, some scholars suggest investigating ambidexterity at the individual level as a promising direction for future research ${ }^{[3]}$. Hence, this paper intends to investigate managers' context ambidexterity.

Managers are embeddedness of individuals in organizational network. In the interaction with subordinates, managers form different network construct-formal and informal network. To date, increasing research explores managers' behavior by use of network theory and methods, but few studies pay attention to the interplay or consistency between formal and informal network and its effects. Indeed, this separation destroys the authority of managers [4]. Further, leadership is a complex adaptive system (CAS), managers need continually carry out contextual explorative activities to adapt the new environment for achieving sustainable development in a dynamic environment. On the other hand, managers also need make full use of existing context and resources to ensure profitability. In addition, in uncertain environment, a single formal or informal behavior do not effectively deal with complex information, and is not conducive to adapt the complex environment for the organization. Therefore, this paper aims to explore managers' consistency between formal and informal network, and its effect on contextual ambidexterity. This will make contributions on the literature about network consistency and context ambidexterity.

\section{Theory and Hypotheses}

\subsection{Consistency between formal and informal network}

Formal and informal factors coexist in the organization. Recently, some scholars have begun to explore the interaction of formal and informal networks at the organizational level. For example, Kuiper's analyzed the impact of the consistency between informal friend network and trust network and authority network on organizational identity, and points out that both have a positive impact on organizational identity, but the impact of consistency between formal authority network and informal trust network was greater [4]. Soda and Zaheer researched the effect of consistency between formal authority and workflows network and informal network on employee performance [5]. White et al. presented the concept of pluralized leadership from the perspective of formal and informal network [6]. These researches provide a path to explore the managers' formal and informal networks and its interaction.

In our theoretical model, we propose hypotheses about the outcomes of interaction of formal and informal networks connecting managers. We conceive formal network as networks of managers connecting subordinates through either reciprocal or sequential interdependencies. In addition, authority is also a formal relation, including hierarchy, approval, and verification-based ties. Informal networks can serve to support the relationship of formal relations between managers and subordinates. Consistency is the extent of similarity in their interaction patterns across networks. When consistency is high, managers can easily conduct management activities in given context.

\subsection{Contextual ambidexterity}

Contextual ambidexterity means a balance between opposing yet independent and complementary behaviors. Such as, organizations need to pay attention to discipline and point out the direction for members to make better use of existing products, but also need to provide members with trust and support to enable them to pursue explorative personal behavior. However, excessive attention to discipline may lead to exhaustion of members, lower expectations, and over-emphasis on trust and support may hinder the completion between members [1]. Based on these literatures, contextual ambidexterity at the manager level is a manager's abilities of contextual explorative and exploitative related with a given context.

To date, many researchers focus on the outcomes of contextual ambidexterity. For example, contextual ambidexterity plays a positive role in the complex organizational behavior and organizational ambidexterity 
[2]; contextual ambidexterity has a positive effect on the innovation of new products. In addition, some scholars have begun to explore the effect of leaders in contextual ambidexterity activities. Such as, the role of leadership in enabling contextual ambidexterity; the influence of leaders' learning on organizational learning from the perspective of contextual ambidexterity. All these do not involve the relationship between the interaction of managers' network and contextual ambidexterity. Indeed, in the given organizational context, the interplay of mangers' network with subordinates can affect management activities.

\subsection{The effect of the consistency between formal and informal} network on contextual ambidexterity

Researchers have suggested that contextual factors need to be considered in managers' behavior research. Because managers are embeddedness of individuals in a unique organizational context. Managers are regarded as the key constructors of organizational contexts. Gibson and Birkin Shaw examine the role of leaders in creating discipline, stretch, trust and support to build a supportive context for contextual ambidexterity [1]. Neanic and Vera explore the role of transformational leadership in promoting contextual ambidexterity [7]. Likewise, leadership is still a crucial factor and stable role in contextual explorative and exploitative activities [8]. Contextual ambidexterity provides opportunities to study how leaders accomplish high levels of exploration and exploitation in facing with constantly changing environment ${ }^{[9]}$.

Indeed, on the one hand, leaders need to continually carry out contextual explorative activities to adapt the new environment for sustainable development; on the other hand, they need to make full use of contextual exploitative activities to ensure profitability. Furthermore, under conditions of uncertainty, although researches examine the effect of leaders' behaviors on contextual ambidexterity, the specific mechanism is not clear, especially in social context. As mentioned earlier, mangers exist in organizational network, and consistency between formal and informal network affect organizational identity [5]. In the interaction between managers and subordinates, when the degree of organizational identity is high, it can promote managers conducting contextual explorative and exploitative activities. Thus, these arguments suggest the following hypothesis.

H1: Mangers' consistency between formal reciprocal workflow and informal emotional network has U-shaped relationship with contextual ambidexterity.

H2: Mangers' consistency between formal sequential workflow and informal emotional network has U-shaped relationship with contextual ambidexterity.

H3: Mangers' consistency between formal authority and informal emotional network has U-shaped relationship with contextual ambidexterity.

\section{Method and results}

\subsection{Method}

Data for the current study were obtained by surveying 108 managers employed in large firms in Shanghai, Nanjing, Xi'an of China. The key measures were originally developed in English, and we used the backtranslation procedure to translate these measures into Chinese.

\section{Consistency between formal and informal network}

Network data were consisted of formal workflow network and authority network, and informal emotional network. Workflows and authority network were measured using the scale developed by Soda and Zaheer [5]. Workflows network include formal reciprocal workflows network and sequential workflows network. Informal emotional network was assessed using Luo's ${ }^{[10]}$ developmental scale. We adopted Soda and Zaheer's method to analyze the network data, and then captured the independent variables. More precisely, we used the CONCOR algorithm of the structural equivalence procedure in UCINET to measure consistency across the networks.

\section{Contextual ambidexterity}

We measured contextual ambidexterity using Fist and Dostaler's ${ }^{[11]}$ 6-item scale, Managers participants responded to all the items using a 7-point scale ranging from " $1=$ strongly disagree" to " $7=$ strongly agree". Cronbach's alpha was 0.82 .
Control variables

Due to potential demographic effects on managers' contextual ambidexterity, we controlled for manager position, age, education.

\subsection{Results}

\subsubsection{Descriptive statistics}

Table1 demonstrates the means, standard deviations, and the correlations among all the study variables.

Table1 Means, standard deviations, and correlations $(\mathrm{N}=108)$

\begin{tabular}{|c|c|c|c|c|c|c|c|c|}
\hline Variable & $\mathrm{M}$ & SD & 1 & 2 & 3 & 4 & 5 & 6 \\
\hline $\begin{array}{l}\text { 1.Manager } \\
\text { position }\end{array}$ & 2.47 & .63 & & & & & & \\
\hline 2.Manager age & 1.20 & .25 & -.19 & & & & & \\
\hline $\begin{array}{l}\text { 3.Manager } \\
\text { education }\end{array}$ & 2.94 & .60 & .18 & -.04 & & & & \\
\hline $\begin{array}{l}\text { 4.Consistency } \\
\text { between formal } \\
\text { reciprocal } \\
\text { workflow and } \\
\text { informal } \\
\text { emotional } \\
\text { network }\end{array}$ & .41 & .18 & -.01 & -.01 & .05 & & & \\
\hline $\begin{array}{l}\text { 5.Consistency } \\
\text { between formal } \\
\text { sequential } \\
\text { workflow and } \\
\text { informal } \\
\text { emotional } \\
\text { network }\end{array}$ & .44 & .18 & .03 & $-.23^{*}$ & $-.22^{*}$ & $.38^{* *}$ & & \\
\hline $\begin{array}{l}\text { 6. Consistency } \\
\text { between formal } \\
\text { authority and } \\
\text { informal } \\
\text { emotional } \\
\text { network }\end{array}$ & -.04 & .19 & -.08 & .07 & .14 & -.01 & .03 & \\
\hline $\begin{array}{l}\text { 7.Contextual } \\
\text { ambidexterity }\end{array}$ & 5.26 & .89 & .01 & $-.25^{* *}$ & -.12 & $.22^{*}$ & -.09 & -.17 \\
\hline
\end{tabular}

${ }^{*} p<0.05$ (two-tailed), ${ }^{* *} p<0.01$

\subsubsection{Hypothesis testing}

We tested our theory using hierarchical regression analyses. Table 2 lists the results. As shown, the consistency between formal reciprocal workflows network and informal emotional network first low and then increase contextual ambidexterity abilities in a U-shaped relationship ( $\beta=0.16, p<0.05$, model 3 ), providing support for Hypothesis 1 . Hypothesis 2 proposes a U-shaped relationship between consistency of formal sequential workflows network and informal emotional network and contextual ambidexterity. This hypothesis is supported $(\beta=0.29, \mathrm{p}<$ 0.1 , model 4). Also as expected, consistency between authority network and informal emotional network has a U-shaped relationship with contextual ambidexterity ( $\beta=0.15, p<0.1$, model 5$)$, so Hypothesis 3 is supported. Therefore, all these three hypotheses are supported. Further, In the model 6, we put all the variables into regression analysis, but the results are not good, which manifests that we adapt the regression analysis to examine the hypothesis is appropriate.

Table 2 Results of hierarchical regression analysis $(\mathrm{N}=108)$

\begin{tabular}{lllllll}
\hline & Modle1 & Modle2 & Modle3 & Model4 & Model5 & Modle6 \\
\hline Constant & -0.00 & -0.00 & -0.16 & -0.24 & -0.17 & $-0.38^{* *}$ \\
& $(-0.00)$ & $(-0.00)$ & $(-1.47)$ & $(-1.45)$ & $(-1.36)$ & $(-2.15)$ \\
Manager & -0.01 & -0.01 & -0.06 & -0.03 & -0.06 & -0.08 \\
position & $(-0.15)$ & $(-0.07)$ & $(-0.63)$ & $(-0.35)$ & $(-0.61)$ & $(-0.86)$ \\
Manager age & $-0.26^{* * *}$ & $-0.34^{* * *}$ & $-0.30^{* * *}$ & $-0.33^{* * *}$ & $-0.26^{* *}$ & $-0.25^{* *}$ \\
& $(-2.74)$ & $(-3.74)$ & $(-3.25)$ & $(-3.59)$ & $(-2.06)$ & $(-2.50)$ \\
Manager & -0.13 & $-0.21^{* *}$ & $-0.17^{*}$ & $-0.17^{*}$ & $-0.25^{* *}$ & $-0.18^{*}$ \\
education & $(-1.33)$ & $(-2.20)$ & $(-1.81)$ & $(-1.76)$ & $(-2.50)$ & $(-1.75)$ \\
Consistency & & $0.35^{* * *}$ & $0.41^{* * *}$ & $0.35^{* * *}$ & $0.32^{* * *}$ & $0.39^{* * *}$ \\
between & & $(3.69)$ & $(4.26)$ & $(3.73)$ & $(2.88)$ & $(3.88)$ \\
formal & & & & & & \\
reciprocal & & & & & & \\
workflow & & & & & & \\
and informal & & & & & & \\
emotional & & & & & & \\
network & & $-0.34^{* * *}$ & $-0.27^{* * *}$ & $-0.32^{* * *}$ & $-0.24^{* *}$ & $-0.24^{* *}$ \\
$\begin{array}{l}\text { Consistency } \\
\text { between }\end{array}$ & & $(-3.36)$ & $(-2.67)$ & $(-3.22)$ & $(-2.31)$ & $(-2.18)$ \\
formal & & & & & & \\
sequential & & & & & &
\end{tabular}




\begin{tabular}{|c|c|c|c|c|c|c|}
\hline $\begin{array}{l}\text { workflow } \\
\text { and informal } \\
\text { emotional } \\
\text { network }\end{array}$ & & & & & & \\
\hline $\begin{array}{l}\text { Consistency } \\
\text { between } \\
\text { formal } \\
\text { authority } \\
\text { and informal } \\
\text { emotional } \\
\text { network }\end{array}$ & & $\begin{array}{l}-0.10 \\
(-1.11)\end{array}$ & $\begin{array}{l}-0.12 \\
(-1.40)\end{array}$ & $\begin{array}{l}-0.11 \\
(-1.26)\end{array}$ & $\begin{array}{l}-0.08 \\
(-0.53)\end{array}$ & $\begin{array}{l}-0.09 \\
(-0.92)\end{array}$ \\
\hline $\begin{array}{l}\text { Squared } \\
\text { consistency } \\
\text { between } \\
\text { formal } \\
\text { reciprocal } \\
\text { workflow } \\
\text { and informal } \\
\text { emotional } \\
\text { network }\end{array}$ & & & $\begin{array}{l}0.16^{* *} \\
(2.35)\end{array}$ & & & $\begin{array}{l}0.15^{* *} \\
(2.17)\end{array}$ \\
\hline $\begin{array}{l}\text { Squared } \\
\text { consistency } \\
\text { between } \\
\text { formal } \\
\text { sequential } \\
\text { workflow } \\
\text { and informal } \\
\text { emotional } \\
\text { network }\end{array}$ & & & & $\begin{array}{l}0.29^{*} \\
(1.69)\end{array}$ & & $\begin{array}{l}0.18 \\
(0.98)\end{array}$ \\
\hline $\begin{array}{l}\text { Squared } \\
\text { consistency } \\
\text { between } \\
\text { formal } \\
\text { authority } \\
\text { and informal } \\
\text { emotional } \\
\text { network }\end{array}$ & & & & & $\begin{array}{l}0.15^{*} \\
(1.72)\end{array}$ & $\begin{array}{l}0.09 \\
(0.94)\end{array}$ \\
\hline$R^{2}$ & 0.08 & 0.23 & 0.27 & 0.26 & 0.21 & 0.29 \\
\hline Adjusted $R^{2}$ & 0.06 & 0.19 & 0.22 & 0.20 & 0.16 & 0.23 \\
\hline $\mathrm{F}$ & 3.08 & 5.15 & 5.40 & 4.91 & 3.89 & 4.52 \\
\hline
\end{tabular}

$t$ statistics in parentheses

${ }^{*} p<0.10,{ }^{* *} p<0.05,{ }^{* * *} p<0.01$

\section{Conclusion and Discussion}

In the study, we adopt hierarchical regression analysis to understanding contextual ambidexterity, and examine the effect of managers' network consistency. Through empirical analyses, we conclude that the consistency between formal network and informal emotional network first low and then increase contextual ambidexterity abilities in a U-shaped relationship. Then we explain the conclusion using CAS theory.

From the perspective of complex adaptive systems (CAS), mangers are in the interactive network of "legitimate system" (formal networks) and "shadow systems" (informal networks) [12], then create different reciprocities in the CAS system: order; chaos; edge of chaos. "Order" is conducive to the development of managers exploitative activities; "edge of chaos" can prompt managers explorative activities. When the goals between mangers and subordinates are not alignment, and emotional communication is less, the interaction of their behaviors is in a chaotic state. Thus, managers' network consistency is low, which is not only conducive to managers' contextual exploitative activities, but also managers

interplay 1 communication), their behaviors are in orderly state, and the network consistency is high. Thus, it is advantage to achieve contextual exploitative activities. But when part aims are same, but others are not, "edge of chaos" emerges in the relationship between mangers and subordinates. That can promote managers' contextual explorative activities. Therefore, the consistency between managers' formal and informal network first low and then increase contextual ambidexterity abilities in a U-shaped relationship.

\section{References}

[1] C. B. Gibson and J. Birkin Shaw: The antecedents, consequences, and mediating role of organizational ambidexterity. Academy of Management Journal, Vol. 47-2(2004), p. 209-226.

[2] A. Carmeli and M. Y. Halevi: How top management team behavioral integration and behavioral complexity enable organizational ambidexterity: The moderating role of Contextual ambidexterity. Leadership Quarterly, Vol. 20-2 (2009), p.207-218.

[3] A. K. Gupta, K. G. Smith and C. E. Shelley: The interplay between exploitation and exploitation. Academy of Management Journal. 49 (2006), p. 693-706.

[4] K. J. Kuiper's: Formal and informal network coupling and its relationship to workplace attachment. Sociological Perspectives, Vol. 52-4 (2009), p. 455-479.

[5] G. Soda and A. Zaheer: A network perspective on organizational architecture: Performance effects of the interplay of formal and informal organization. Strategic Management Journal, 33 (2012), p.751-771.

[6] L. White, G. Currie and A. Lockett: The enactment of plural leadership in a health and social care network: The influence of institutional context. Leadership Quarterly, Vol. 25-4 (2014), p.730-745.

[7] L. A. Neanic and D. Vera: Transformational leadership and ambidexterity in the context of an acquisition. Leadership Quarterly, Vol. 20-1 (2009), p. 19-33.

[8] Q. Cao, Z. Smise and H. Zhang: Modelling the joint impact of the CEO and the TMT on organizational ambidexterity. Journal of Management Studies, Vol. 47-7 (2010), p. 1272-1296.

[9] A. H. Lifelore, N. D. H. Deanne, K. Anne: Exploring the role of Leadership in enabling contextual ambidexterity. Human Resource Management, Vol. 54 (2015), p.179-200.

[10] J. D. Luo, H. F. Shi and J. Y. Lin: The effect of relationship network on the attitude of computer from the Infiltrative model perspective. Informatization Society Research, Vol. 2 (2002), p. 139-164.

[11] Z. Mohamad and N. O. Siti: Structural ambidexterity vs contextual ambidexterity: Preliminary Evidence from Malaysia. The Social Sciences, Vol. 10-6 (2015), p. 1200-1207.

[12] L. H. Jiang, L. Wu and X. Zhang: A theoretical framework of the interplay between formal and informal network impact on organizational adaptation based on CAS theory. Science of Science and Management of S. \& T., Vol. 37-3 (2016), p. 31-42. 